\title{
Petra Košutar i Mislav Kovačić (ur.). Od dvojbe do razdvojbe. Zbornik radova u čast profesorici Branki Tafri. Zagreb, Ibis grafika, 2018.
}

Zbornik radova Od dvojbe do razdvojbe urednikâ Petre Košutar i Mislava Kovačića objavljen je 2018. u povodu sedamdesetoga rođendana znanstvenice i sveučilišne profesorice Branke Tafre. Obuhvaća trideset pet radova većinom na hrvatskom, ali i na srpskom, njemačkom i engleskom jeziku, kojima trideset osmero autora odaje počast našoj istaknutoj lingvistici i kroatistici. Velika je većina radova posvećena lingvističkim - leksikološkim, leksikografskim, rječotvornim, gramatičkim, prozodijskim i jezičnopovijesnim - pitanjima, ali neki obrađuju i književne, filozofske te semiotičke teme.

Radovi su podijeljeni u dvije cjeline. Prva, naslovljena Riječ u strujanjima sadašnjosti, okuplja one koji svoju temu obrađuju sinkronijski, dok su u drugu, pod naslovom Riječ u tragovima prošlosti, svrstani radovi koji se odlikuju dijakronijskim pristupom. Kako u »Uvodu« ističe urednica Petra Košutar, takva je podjela motivirana, među ostalim, i slavljeničinom knjigom Jezikoslovna razdvojba, koja je uz to utjecala i na odabir naslova zbornika. Osim samih radova u zborniku je objavljena i Biografija prof. dr. sc. Branke Tafre (str. XI-XIV) te Bibliografija prof. dr. sc. Branke Tafre (str. XV-XXXI), kako je to u izdanjima ovoga tipa uobičajeno. Obuhvaćeno je uz to i nekoliko osobnih osvrta na slavljenicu: kao učitelji učenici obraćaju joj se Radoslav Katičić (str. XXXIII) i Milenko Popović (str. XXXIV), kao kolegica kolegici Diana Stolac (str. 269-270), a kao »čovjek čovjeku« Velimir Piškorec (str. 513). I urednik Mislav Kovačić u Zaslovku (str. 514-528) na topao način piše o Branki Tafri kao otvorenu čovjeku, minucioznoj stručnjakinji i empatičnoj učiteljici. Zbornik obuhvaća i Kazalo imena (str. 529-545) te Podatke o suradnicima (str. 546-548).

Prvu cjelinu zbornika otvara rad Matee Birtić Vrste dopuna u Bazi hrvatskih glagolskih valencija (str. 3-19). Autorica u njemu opisuje dopune tzv. psiholoških glagola, jedne od trideset četiriju semantičkih skupina glagola koje su u Bazi izdvojene i jedine koja je dosad iscrpno opisana i mrežno dostupna. Izdvaja pritom ukupno deset vrsta dopuna: nominativnu, genitivnu, dativnu, akuzativnu, instrumentalnu, predikatnu, priložnu, prijedložnu, infinitivnu i rečeničnu.

Slijedi rad Sinonimija u višerječnim svezama hrvatskoga jezika (str. 21-30), u kojem Goranka Blagus Bartolec na temelju primjera iz Kolokacijske baze hrvatskoga jezika Instituta za hrvatski jezik i jezikoslovlje analizira sinonimne odnose u hrvatskim višerječnim svezama, i to kolokacijski svezama, višerječnim nazivima i imenima te slobodnim svezama. Izdvaja pritom ukupno devet sinonimnih modela, a rezultati pokazuju da je u sinonimskom paru višerječnih sveza jedna sastavnica često ista (npr. bračni krevet i bračna postelja), da parnjake obično povezuje djelomična sinonimija te da mnogobrojni primjeri predstavljaju samo formalne inačice, koje se razlikuju pravopisno ili redom riječi. 
Problematikom razlikovnoga dijalektnoga rječnika bavi se Đuro Blažeka u radu Ojednom mogućoj koncepciji izrade 'razlikovnih rječnika' između bliskih govora (str. 3143). Analizirajući leksik govora Preloga i govora Kotoribe, koji oba pripadaju donjomeđimurskomu dijalektu, uočava da se leksički parnjaci u tim govorima mogu razlikovati na pet načina: a) različitim tvorbenim sredstvima, b) u jednom parnjaku dolazi do fonološke promjene ili morfonološke smjene koja u drugom izostaje, c) parnjaci su onomatopeje s različitim planom izraza, d) dva potpuno različita leksema, e) parnjaci su lažni prijatelji. Najbrojnije su pritom kategorije b) i c), pri čemu nisu obuhvaćeni parovi riječî koje se razlikuju samo očekivanim fonološkim izoglosama.

Području filozofije jezika pripada rad Dušana Dožudića Govor između rečenice i sadržaja: opaske o semantici (ne)upravnoga (str. 45-64), u kojem se autor na tragu Gottloba Fregea bavi semantičkom analizom rečenica upravnoga i neupravnoga govora. Autor najprije razmatra istinitosne uvjete takvih rečenica, njihov sadržaj i međusobne veze, a zatim se na temelju toga osvrće na pojedina objašnjenja upravnoga i neupravnoga govora u hrvatskim gramatikama te upozorava na njihove nedostatke.

U radu Domen primene lekseme kao segment leksičkog značenja (str. 65-80) Rajna Dragićević zastupa tvrdnju da je domena primjene leksema dio njegova leksičkoga značenja, zajedno s referencijom, denotacijom, designacijom i konotacijom. Potkrepljuje je empirijski primjerima iz Elektroničkoga korpusa srpskoga jezika te vlastitim psiholingvističkim istraživanjem, pri čemu se usredotočuje na jednu komponentu domene primjene, onu koja se odnosi na pozitivnu ili negativnu ocjenu kolokatorâ.

U frazeološkom radu Može li se sve dovesti u pitanje? (O hrvatskim kolokacijskim svezama i frazemima sa sastavnicom pitanje) (str. 81-93) Željka Fink analizira strukturu i semantiku hrvatskih kolokacijskih sveza i frazema sa sastavnicom pitanje. Najprije obrađuje teorijsko razgraničenje kolokacijskih sveza i frazema, a zatim analizira hrvatske primjere tih složenih jedinica koje sadržavaju sastavnicu pitanje. Kad je riječ o kolokacijskim svezama, najčešća je struktura 'pridjev + imenica', dok je glagolski strukturni tip rjeđi. Kod frazema je pak zabilježena i rečenična struktura. Sama imenica pitanje u analiziranim se višerječnim jedinicama pojavljuje i u svojem osnovnom leksičkom značenju i desemantizirana, djelomice ili potpuno.

Leksikološkom temom bavi se Darinka Gortan Premk u radu Platisemija i similisemija u polisemantičkoj strukturijedne lekseme (str. 95-105). Termin platisemija uvela je istaknuta srpska lingvistica Irena Grickat 1967. kako bi označila »širokoznačnost «, tj. posebnu vrstu višeznačnosti za koju je karakteristično da se među pojedinim značenjima leksema ni povijesno ni sinkronijski ne može ustanoviti da je neko ishodišno, nasuprot ostalima izvedenima. Sama je autorica članka pak uvela termin similisemija kako bi označila sposobnost leksemâ iz leksičko-semantičke skupine »čovjek« da označuju i referente koji se odnose na životinju. Rad se bavi analizom platisemije i similisemije te njihovim razgraničenjem od sličnih pojava. 
Slijedi članak O brojevima (str. 107-111), u kojem Jadranka Gvozdanović, istaknuta lingvistica poznata (među ostalim i) po radovima o toj vrsti riječi, odaje priznanje Branki Tafri jer je podvrgnula kritici tradicionalni pristup brojevima u jezikoslovnoj kroatistici i ponudila njihov adekvatniji opis. U članku se analizira morfološko i sintaktičko ponašanje brojeva te se navodi kako brojevi kao kvantifikatori mogu preuzeti različite sintaktičke funkcije, što onda može objasniti i njihova različita značenja.

U zanimljivom radu Prijedlozi kao rječničke natuknice (str. 113-125) Ivana Matas Ivanković analizira hrvatske jednojezične rječnike s obzirom na način na koji pristupaju opisu prijedloga. Ističe kako se u njima zanemaruje sintaktička funkcija kao glavna odlika prijedloga te u skladu s njom ističe - u duhu pristupa koji već odavno odlikuje druge slavenske lingvističke tradicije - da u prijedloge treba ubrojiti ne samo tradicionalne primarne nego i sekundarne prijedloge, i to i jednorječnice (npr.prilikom, glede) i višerječnice (npr. za razliku od, bez obzira na).

Području semiotike pripada članak Što može reklamna topografija? Funkcije tipografskog oblikovanja na primjeru suvremenih hrvatskih reklama (str. 127-142), u kojem Lucia Miškulin Saletović i Mislava Bertoša istražuju funkciju tipografskoga oblikovanja u suvremenih hrvatskim reklamama prehrambenih proizvoda te proizvoda za njegu tijela i odjeće. Ističu kako u jednoj skupini reklama tipografija ima samo funkciju vizualne organizacije teksta, dok u drugoj bogatim asocijacijama pobuđuje pažnju i interes primatelja.

U članku Kroz leksikologiju i semantiku (str. 143-159) Ida Raffaelli tematizira odnos rječotvorja, leksikologije i semantike. Oslanjajući se na modele morfosemantičkih i leksikalizacijskih obrazaca, ističe potrebu za čvrstom povezanošću tih triju disciplina kako bi se mogao što potpunije opisati način na koji se proširuje leksičko blago nekoga jezika.

Ermina Ramadanović i Barbara Kovačević u članku Prozodijska tvorba u hrvatskomjeziku (str. 161-175) analiziraju jedan rječotvorni problem čijemu je razjašnjavanju pridonijela i slavljenica. Unutar tzv. unutarnje tvorbe, u sklopu koje nove leksičke jedinice nastaju promjenom rječotvorne osnove, autorice razlikuju fonemsku i prozodijsku tvorbu, pri čemu se prva provodi promjenama u fonemskom sastavu osnove, a druga promjenom naglaska i(li) duljine. Naglašavaju potrebu da se prozodijska tvorba u sklopu tvorbenih načina razmatra samostalno.

U članku Simbolika ili arbitrarnost - o brojevima četiri i četrnaest u frazemima (na primjeru češkoga, makedonskoga i hrvatskoga jezika) (str. 177-188) Slavomira Ribarova bavi se frazemima koji sadržavaju sastavnicu četiri i četrnaest. Dok se frazemi s brojem četiri rabe u sva tri analizirana jezika, frazemi s brojem četrnaest pojavljuju se samo u češkom i makedonskom. Za većinu je frazema motiviranost uporabe broja lako ustanoviti, ali neki, osobito oni s brojem četrnaest, upućuju na arbitrarnost uporabe.

Ljiljana Šarić u minucioznom članku Bliskoznačni prefigirani glagoli: konstrukcija značenja i scenariji (str. 189-214) na temelju primjera iz korpusa hrWaC analizira 
razlike u značenju i konstrukcijske profile bliskoznačanih glagola izvedenih prefiksima $u_{-}, o(b)_{-}, n a-, i z-\mathrm{i} z a-$ od osnovnih mastiti, blatiti i crniti. Iako prefiksi ishodišno imaju prostorna značenja, za sve analizirane osnovne glagole potvrđene su i izvedenice s metaforičkim i metonimijskim pomacima u značenju. Kako ističe autorica, ako su razlike u prostornim scenarijima prefikasa veće, veća je vjerojatnost da će se dotični prefigirani glagoli učestalo rabiti. Ako je razlika manja, jedan će vjerojatno dominirati, a drugi će se povući iz uporabe ili semantički specijalizirati.

U iznimno zanimljivom članku Višestruka ekvivalencija: izazovi i rješenja (str. 215-223) Danko Šipka obrađuje problem višestruke međujezične ekvivalencije, tj. slučajeve kad jednomu leksemu ishodišnoga jezika odgovaraju dva ili više leksema u odredišnom jeziku. Takvi problemi predstavljaju izazov za prevođenje, nastavu drugoga jezika i leksikografiju, a autor u članku donosi taksonomiju višestruke ekvivalencije te naznačuje moguća leksikografska rješenja.

Slijedi rad Od kolokacije do frazema (str. 225-237), u kojem Marija Turk analizira ustaljene spojeve pridjeva i imenice te u njima pokušava razgraničiti kolokacije od frazema. Među tim dvjema složenim jedinicama pritom nema čvrste granice, nego ih odlikuje kontinuiran prijelaz, pa je razgraničenje samo relativno. Može se provoditi na temelju semantičkih kriterija (monosemija, polisemija, homonimija i sinonimija) te funkcionalne diferencijacije.

U članku Labor omnia vincit (o radu i radinosti u zoonimnoj frazeologiji) (str. 239251) Ivana Vidović Bolt analizira hrvatske i poljske zoonimne frazeme kojima se opisuje odnos prema radu. Zaključuje kako su životinje u njima prikazane kao marljive i ustrajne, ali i kao umorne i iscrpljene. Stereotipne predodžbe o životinjama podudaraju se u dvama analiziranim jezicima, iako u njima nema uvijek ekvivalenata za sve životinjske sastavnice (npr. u poljskim frazemima izostaje u hrvatskim posvjedočena krtica).

Prvu cjelinu sa sinkronijskim radovima zatvara iznimno vrijedan članak Ajme naslova! Uzvik, pridjev, prilog i imenica ajme (str. 253-268) Jasne Vince. Autorica u njemu analizira što se u suvremenoj razgovornoj uporabi događa s riječju ajme, koja se obično određuje kao uzvik. Ta riječ naime prodire u različite sintaktičke okoline mijenjajući svoju vrstovnu pripadnost, ali uglavnom ne i oblik, pa čak ni osnovno značenje. Kao imenica ajme se ipak katkad može i deklinirati, a kao pridjev i prilog komparirati.

Drugu, dijakronijsku cjelinu otvara članak Ankice Čilaš Šimpraga Branka i ostala imena s osnovom brani u hrvatskoj antroponimiji (str. 273-287). Autorica ističe starinu imenâ s tom osnovom, prati njihovo pojavljivanje kroz prošlost te objašnjava razloge koji su doveli do njihova smanjenoga nadijevanja (na područjima koja nisu bila pod turskom vlašću zbog posttridentskoga preferiranja svetačkih imena) ili ponovnoga češćega pojavljivanja (odXIX. st. zbog nacionalne simbolike).

Problematikom početaka hrvatskoga standardnoga jezika bavi se Stjepan Damjanović u članku Približavanje standardu (napomene o hrvatskom jeziku u 17. st.) (str. 289-298). Autor analizira društvene prilike u kojima se u 17. st. razvija hrvat- 
ska pismenost i sve jače usmjerava prema štokavštini, pri čemu ističe nemogućnost povlačenja čvrste granice između standardnoga i predstandardnoga razdoblja.

U članku Rukopisna latinska gramatička Šime Starčevića. Prvo čitanje (str. 299315) Šime Demo prikazuje Starčevićev opis latinske gramatike iz ostavštine svećenika Martina Davorina Krmpotića. Pronađen je u Arhivu Hrvatske provincije Družbe Isusove te je obrađen u sklopu istraživačkoga projekta Hrvatska pisana baština od 17. do 19. st. voditeljice Diane Stolac s Filozofskog fakulteteta Sveučilišta u Rijeci.

Georg Holzer u radu Generativistische Beschreibung ausgewählter prosodischer Alternationen im Neuštokavischen (str. 317-325) iz generativističke perspektive klasificira neke od prozodijskih alternacija u novoštokavskom. U obzir se pritom uzimaju morfonološke smjene koje su nastale uslijed glasovnih zakona i analogije.

Slijedi članak O tvorbi imenica i pridjeva u Jurinovoj Slovkinji (str. 327-343), u kojem Marijana Horvat i Vladimira Rezo analiziraju način na koji je obrađena tvorba imenica i pridjeva u gramatici Slovkinja slavnoj slovinskoj mladosti Josipa Jurina (Venecija, 1793). Autorice tvorenice razvrstavaju prema tvorbenim načinima, a određuju ih u odnosu na potvrde u Rječniku hrvatskoga ili srpskoga jezika JAZU-a.

Jagoda Jurić-Kappel u članku Zlatno doba bečke slavistike: od Miklošiča do Trubeckoja (str. 345-354) donosi pregled povijesnoga razvoje bečke slavistike od njezina osnivanja 1849., kada prvim profesorom postaje Franc Miklošič, do 1938., kad je preminuo njezin tadašnji predstojnik Nikolaj Trubeckoj. Važnu su ulogu u prikazanom razdoblju na bečkoj slavistici imali i Vatroslav Jagić te Milan Rešetar.

U članku Preporodni hrvatsko-njemački rječnik 'Kleines illirisch-deutsches Wörterbuch für die Jugend der Militär-Grenzschulen' Ladislava Škrobotha (1839; 355369) Amir Kapetanović opisuje dosad neobrađeni školski priručnik koji je bio namijenjen učenicima u Vojnoj krajini. U rječniku su sačuvane potvrde nekih tadašnjih neologizama (npr. kišobran), a zanimljiv je i zato što pokazuje kako se u to doba širila ilirska štokavština i na kajkavskom području.

Prozodijskom se temom bavi članak Naglasak u rukopisnom rječniku Bartola Kašića (1599; 371-384) Mate Kapović. Autor u njemu opisuje znakovni sustav kojim se Kašić služi, određuje narav naglasnoga sustava (broj i vrste prozodema te njihovu raspodjelu), a donosi i naglasni opis pojedinih leksema te prikaz naglasnih paradigama i svojstava unutar morfologije i tvorbe.

U članku Profano - sakralno (str. 385-399) Pavao Knezović analizira baroknu figuru kontrasta između profanoga i sakralnoga u djelu Testimonium bilabium najplodnijega bosanskoga franjevačkoga pisca u XVIII. st. Filipa Lastrića. Navodi brojne primjere iz toga djela kojima ilustrira način na koji se Lastrić služio omiljenom baroknom figurom kontrasta.

U članku Proto-Slavic *ędro 'kernel, core' and *ědro 'bosom' (str. 401-405) Ranko Matasović analizira etimologiju dviju hrvatskih bliskozvučnica jédro ijëdro. Autor u članku nastoji pokazati da te dvije riječi imaju isti praindoeuropski izvor.

Sljedeći je članak Milice Mikecin O podrijetlu i razvoju kršćanskoga značenja staroslavenske riječi pastyrb (str. 407-420). Autorica u njemu obrađuje etimologiju ri- 
ječi pastyrъ, koja je prvotno značila ‘čuvar stada ovaca', a zatim je počela označivati i Isusa Krista po uzoru na grčku riječ kuju je prevodila poimēn. Ističe kako je od glagola pasti izveden i glagol sъpasti sa značenjem 'dognati stado na pašu; zaštititi stado', a u kršćanstvu je dobio i značenje 'izbaviti od grijeha'.

U članku Čudesa svetoga Jeronima u Troji (u glagoljičnom Transitu svetoga Jerolima iz 1508. godine) (str. 421-427) Anica Nazor tematizira poznati glagoljički prijevod talijanskoga popularnoga predloška Transito de S. Girolamo. U očuvanim primjercima nedostaje opis Jeronimovih čudesa u Troji, no sačuvana su u latiničnom prijepisu Lovrijenca Vejanina iz 1670. Na temelju toga prijepisa autorica je priredila tekst onih čudesa koja nedostaju u glagoljičkim primjercima Transita.

Analizom nazivâ za posude i pribor za jelo u hrvatskom, poljskom, ruskom, slovačkom i češkom u usporedbi sa staroslavenskim i indoeuropskim bavi se Neda Pintarić u članku Zajednički slavenski korijeni za nazive posuda i pribora za jelo (str. 429-445). Zaključuje da su predmeti od drva, pruća, gline, kože, metala i platna imali slavenske korijene, a oni od stakla i kamena nisu, nego su nazivi za njih još u praslavensko doba preuzimani iz latinskoga, grčkoga i germanskoga.

Dubravka Sesar u članku Slavenski jezici u 17. st. (str. 447-462) tematizira razvoj slavenskih jezika u 17. st. Ističe da je to razdoblje za zapadnoslavenske jezike krizno zbog nepovoljnoga utjecaja društvenih prilika na kulturne procese, dok se istočnoslavenski upravo tada počinju postupno približavati zapadnoeuropskim uzorima.

Članak O Veberovoj sintaksi pridjeva: je li hrabar Zrinski hrabar, a Aleksandar Veliki velik? (str. 463-475) Anastazije Vlastelić tematizira Veberovu funkcionalnu podjelu pridjeva prema rečeničnoj službi atributa, epiteta, apozicije i predikata. Ta je podjela doživjela brojne kritike već u vrijeme kad se pojavila, a Veber ju je branio i u svojem članku O pridavniku, čija je analiza glavni predmet ovoga rada.

Antonija Zaradija Kiš u članku Animalističke predodžbe ljudske naravi: Cvêtı vsake mudrosti u hrvatskoglagoljskom Vinodolskom zborniku (str. 477-498) analizira na koji se način čovjek i njegovo ponašanje sagledavaju kroz animalističku vizuru $\mathrm{u}$ tom srednjovjekovnom tekstu, prijevodu poznatoga talijanskoga djela Fiore di virtù.

Napokon, u članku 'Jer je Bog tako odredio, da nikada mlađi ne pojede, što stariji ne promisli': hrana u Pričama iz davnine Ivane Brlić-Mažuranić (str. 499-512) Dubravka Zima raspravlja o toposu hrane u tom važnom tekstu hrvatske dječje književnosti. Tumači ga s pomoću četiriju metafora: hrana povezana s majčinstvom, transformacija hrane, nutritivna vrijednost hrane te disciplinarna vrijednost hrane. Članak zaključuje drugu cjelinu radova u zborniku.

Ovaj svečarski zbornik okupio je autorice i autore u čijim je profesionalnim životima Branka Tafra ostavila važan trag - mnogi od njih u svojim prilozima ističu pritom ne samo njezinu stručnost nego i ljudskost. Baveći se s jedne strane suvremenim hrvatskim jezikom - i leksičkim i gramatičkim temama - a s druge poviješću hrvatskoga književnoga jezika - njegovom leksikografijom i gramatografijom 
- Branka Tafra ostavila nam je tematski iznimno raznovrsne radove, s čime se malo koji kroatist njezine generacije može mjeriti. Uz to je kao malo koji kroatist njezine generacije pomno čitala radove drugih te se pozivala na njih u onom što je u njima dobro, a argumentirano ih kritizirala u onom u čemu su griješili. U kulturi u kojoj, kako mi je jednom prilikom rekla, »slabo čitamo jedni druge«, ta se njezina akademska vrlina posebno ističe. S druge strane mnogi njezini radovi u kojima je dovela u pitanje naoko samorazumljiva shvaćanja i dalje čekaju pomne čitatelje i istinsku valorizaciju. Ovaj zbornik, koji sadržava nekoliko nadstandardno zanimljivih i vrijednih radova, važan je korak na tom putu.

PetarVuković 